\title{
Conservation Agriculture to buffer and alleviate the impact of climatic variations in Madagascar: farmers' perception
}

\author{
Eric Penot ${ }^{1,2,{ }^{*}}$, Valentin Fevre ${ }^{3}$, Patricia Flodrops ${ }^{3}$ and Hanitriniaina Mamy Razafimahatratra ${ }^{4}$ \\ ${ }^{1}$ CIRAD, UMR innovation, 34398 Montpellier, France \\ 2 Innovation, Univ Montpellier, Montpellier, France \\ 3 AgroParisTech, Paris, France \\ ${ }^{4}$ FOFIFA, DP SPAD, Antananarivo, Madagascar
}

\begin{abstract}
Conservation Agriculture (CA) has been promoted during the last 15 years in Madagascar to develop a sustainable rainfed agriculture in order to cope with low fertility upland soils, soil erosion, low productivity and erratic rainfall. If CA does provide a better sustainability with adapted cropping patterns when adopted, a question is, whether $\mathrm{CA}$ is able to alleviate the impact of climatic variations thanks to the mulching effect and to which extent. We took the example of medium altitude zones in the Lake Alaotra area to illustrate farmers' perceptions. If climate change is not proven in these areas, climatic variations are very high and erratic rainfall patterns at the beginning of the rainy season induce serious risks of crop failure. Two surveys were implemented in 2013: (i) on CA changing practices of 92 farmers (during the 10 years project duration) and (ii) on the evolution of behavior among 28 farmers who have recently adopted CA (less than 5 years). In CA systems, the mulch contributes to better cropping systems resilience and helps alleviating the effect of climatic variations. If a limited number of farmers have effectively adopted CA practices, in the long run, most farmers have developed innovative cropping systems between conventional agriculture and CA, to address their own constraints, leading to a widespread range of agro-ecological practices. A typology of behavior is presented to identify farmers' strategies regarding risks in a context characterized by multiple uncertainties.
\end{abstract}

Keywords: conservation agriculture / climatic impact alleviation / adaptation to climate change / Lake Alaotra / Madagascar

Résumé - L'agriculture de conservation peut-elle réduire l'impact des variations climatiques à Madagascar? Perceptions paysannes. L'agriculture de conservation (AC) a été promue au cours des 15 dernières années à Madagascar pour développer une agriculture pluviale durable sous fortes contraintes : sols à faible fertilité, érosion des sols, faible productivité et pluies irrégulières. Si l'AC offre une meilleure durabilité avec des modes de culture adaptés, la question est de savoir si elle peut réduire l'impact des variations climatiques grâce à l'effet de paillage (mulch). Nous avons pris l'exemple des zones d'altitude moyenne dans la région du lac Alaotra pour illustrer les perceptions des agriculteurs. Si les changements climatiques ne sont pas prouvés dans ces zones, les variations climatiques sont très importantes et les précipitations irrégulières au début de la saison des pluies induisent de forts risques de mauvaises récoltes. Deux enquêtes ont été mises en œuvre en 2013 : sur l'évolution des pratiques d'AC de 92 agriculteurs (sur la durée du projet de 10 ans) et sur l'évolution du comportement de 28 agriculteurs qui ont récemment adopté l'AC (moins de 5 ans). Dans les systèmes en $\mathrm{AC}$, le mulch contribue à améliorer la résilience des systèmes de culture et aide à réduire l'effet des variations climatiques. Si un nombre limité d'agriculteurs ont effectivement adopté des pratiques en $\mathrm{AC}$, à long terme, la plupart des agriculteurs ont mis au point des modèles de culture intermédiaires entre l'agriculture conventionnelle et l'AC pour répondre à leurs propres contraintes, aboutissant à une vaste gamme de pratiques agro-écologiques. Une typologie des comportements est présentée pour identifier les stratégies des agriculteurs concernant les risques dans un contexte caractérisé par de multiples incertitudes.

Mots clés : agriculture de conservation / atténuation de l'impact climatique / adaptation / Lac Alaotra / Madagascar

*Corresponding author: eric.penot@cirad.fr 


\section{Introduction: Conservation Agriculture for sustainable agriculture}

Lake Alaotra is considered as the rice bowl of Madagascar but the area suffers from significant soil erosion, poor fertility, a high inter-annual variability of rainfall and an increasing population ( $3 \%$ per year). If irrigated rice is considered as a very secure cropping system, rainfed agriculture is still considered as very risky. Developing a sustainable agriculture to overcome such constraints and stabilize production is a real challenge. The Lake Alaotra watershed project (BV-Lac Project, carried out by AFD, French Development Agency) has promoted Conservation Agriculture (CA) from 2003 to 2013 with more than 3000 farmers involved. The project came to an end in June 2013 with the end of the formal extension service in the area. This provides the opportunity to see the impact of technical change at large level with historical depth.

As defined by the FAO in 2008, CA has three main principles:

- minimum soil disturbance;

- soil protection by vegetation cover;

- crop rotation and plant association.

The purpose of CA cropping systems is to stabilize production and increase soil fertility by raising their biological life (Scopel et al., 2004). It has been promoted to reduce labor requirements, to improve soil structure, water conservation, yields and eventually smallholder's income (Scopel et al., 2012). In tropical conditions, the agronomic and ecological effectiveness of CA has been highlighted by numerous studies at plot scale showing positive effect on erosion due to mulch cover (Derpsch, 2005), on structural soil stability and porosity, on infiltration (Scopel et al., 2005), on water runoff (Findeling et al., 2003), resulting in an improved water balance. Cover crops and no-tillage allow an enrichment of the topsoil carbon and organic matter to maintain soil fertility in the long term (Corbeels et al., 2006) as well as an activation of soil micro and macro-fauna (Brevault et al., 2007). The cover crop also helps control weeds. Among CA practices, the mulch is the technical component that is the most likely to reduce climatic risks. However, several studies have also highlighted the limitations of CA, leading to partial adoption only if at all (Corbeels et al., 2014; Giller et al., 2009; Serpantié, 2009; Wezel et al., 2014; Arslan et al., 2014; Andersson and D'Souza, 2014). The impact of CA with appropriate fertilization (Vanlauwe et al., 2014) shows the necessity for ecological intensification to boost CA adoption by farmers. Since the start of the BV-Lac project in 2003, changes and technical innovation have been observed on more than 3000 farmers' plots, showing that farmers have adapted CA to their own constraints and farming structure (Penot et al., 2012).

\section{Conservation agriculture and climatic variations}

The climate of Lake Alaotra region shows:

- a large inter-annual variability of rainfall $(560-1400 \mathrm{~mm} /$ year),

- irregularity of early rains (erratic pattern of monthly rainfall during the first 3 months of the rainy season: the coefficient of variation is $111 \%, 66 \%$ and $181 \%$ in November, December and January respectively (Bruelle, 2014); - the impact of cyclones (erosion).

We are more in a context of "large climatic variations" rather than climate change strictly speaking. Does CA provide sufficient results and resources to significantly reduce the risks of rainfed agriculture in such areas?

In the Alaotra lake region, recent surveys showed the effectiveness of mulching in securing early sowing and increased yields (Bruelle, 2014) with a significant impact on yields when rainfall is below $900 \mathrm{~mm} /$ year (Bruelle et al., 2015). However, there is a real trade-off concerning the use of crop residues either for mulching or livestock feeding (Naudin et al., 2012). In other words, if mulching is generally recognized by farmers as risk-minimizing (alleviating climatic impact), a better immediate economic use of crop residues for livestock rearing can be obtained, making it difficult to convince farmers to adopt CA in the long run. The hypothesis is that farmers are ready to adopt a technical change that can effectively reduce risks and provide a significant and immediate impact in the short/medium term. At the end of the project, the discontinuity in technical advice created a "space of emptiness" and a feeling of "abandon" for some farmers. In 2010, the number of farmers having adopted CA was about 600 farmers (for a total of 3000 farmers within the $\mathrm{BV}$-Lac project) on $410 \mathrm{ha}$. Such adoption of CA is based on a paradigm shift requiring a real transition phase with a long learning process through a dual conversion, both technical (new practices) and behavioral (from an " $a d-h o c$ " short-term logic to long-term "strategic" way of thinking).

Cropping systems incorporating one or more of CA components, without adopting the whole CA "package" seems to be widespread. Such hybrid systems are called Innovative Cropping Systems (ICS). A continuum can be observed between CA and conventional systems (Poletti et al., 2011). The question is whether ICS are able to provide sufficient services to effectively overcome climatic as well as environmental risks (loss of fertility and erosion)?

The objective of this study is thus to analyze CA cropping systems evolution during and after the project as well as farmers' perception on CA's ability to offset climatic risks, taking especially into account the effect of mulching on 2 of the 3 criteria of climate-smart agriculture, i.e. adaptation to climate change and sustainable food security. This requires analyzing cropping systems evolution and adaptation, as well as innovation processes at stake and farmers strategies related to innovation. Mitigation of climate change, the third criterion for climate-smart agriculture (through, e.g. increasing soil carbon content), is not addressed in the present study.

We focus on factors of CA adoption, types of cropping systems effectively adopted and changes in farm trajectories, in particular those contributing to climate-smart agriculture.

\section{Methods}

Agriculture in the Lake Alaotra plain is characterized by irrigated rice $(100000 \mathrm{ha}$, out of which 70000 ha have poor water control), pastures for extensive cattle raising and upland agriculture in the surrounding mountains. The BV-Lac project 


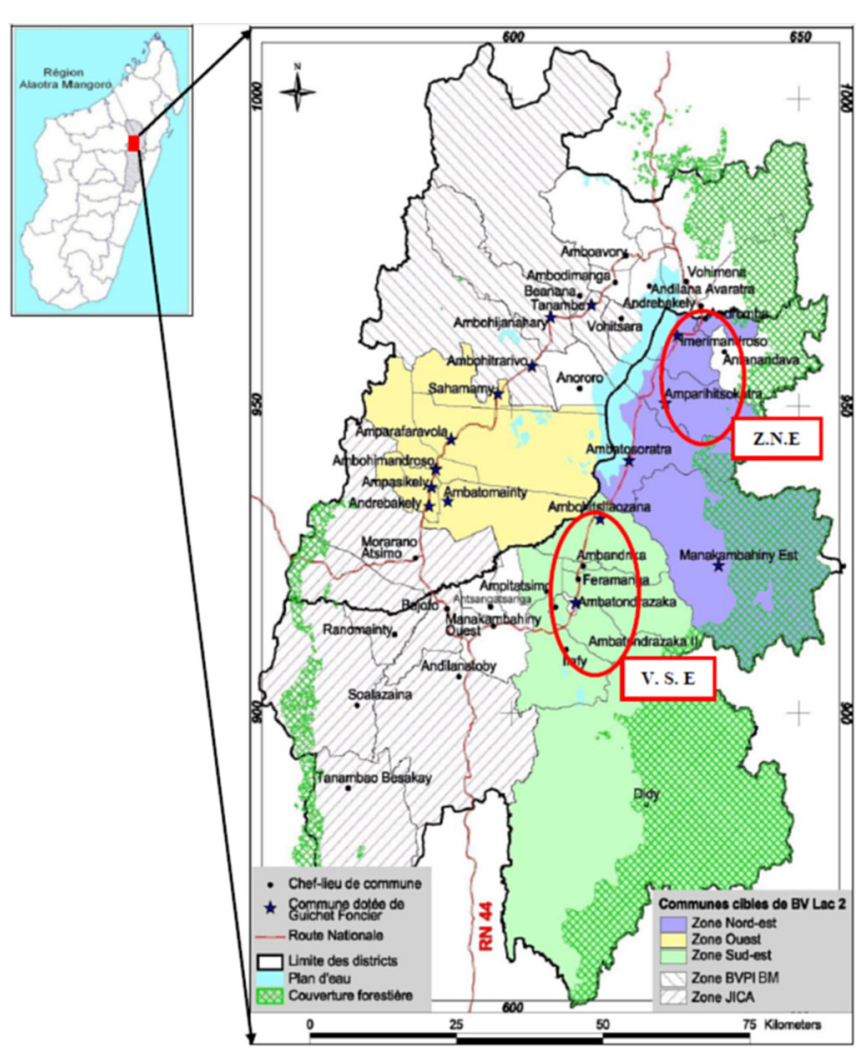

Fig. 1. The two study areas in the former BV-Lac project area at Alaotra lake.

Fig. 1. Les deux zones d'étude dans l'aire du projet BV-Lac au lac Alaotra.

has developed extension activities in the eastern and southern areas of the lake (Fig. 1). The study is based on two representative samples in order to compare the oldest CA plots of the project (longest historical perspective; $n=77$ ) and plots less than 5 year-old $(n=15)$. The two surveys have been implemented during 6 months after project's completion in 2013-2014.

\subsection{Survey \# 1: CA changing practices (92 farmers) on the 10 years project duration}

We interviewed 77 farmers having adopted CA between 2003 and 2009 (representative of a 5-10 years "adoption") and 15 farmers with less than 5 years adoption representative of a recent "adoption". The survey was based on farmers' perception about their cropping systems, expectations and changes in order to overcome the main local constraints. We recorded how farmers received, developed and interpreted the technical information that was given to them by the extension services and how they turned this new knowledge into knowhow and eventually into practices.

\subsection{Survey \# 2: Evolution of behavior among 28 farmers who have recently adopted CA}

The objective of this second survey was to check whether Innovative Cropping Systems (ICS) are robust and can survive the shutdown of project activities. The survey was based on focus-group discussions including 28 farmers from three villages spanning the northern zone mainly composed of tanety (upland situation with rainfed agriculture) and the southern valleys marked by the dominance of irrigated rice and presence of baiboho (colluvial soil with access to water in dry season by capillarity).

Eventually, a SWOT analysis (strengths, weaknesses, opportunities, and threats) was implemented using focus group meetings with local farmers to assess the sustainability criteria of CA. Farming systems characteristics and typology have been published in Fevre et al. (2014). Farming in the area is family-based, hand-operated, sometimes using animal traction, with low input cropping systems and no subsidy. Average farm size is from 2 to 10 ha according to farm types (Durand et al., 2011). The BV-Lac project provides technical assistance and credit through a local credit institution.

\section{Results}

\subsection{The situation in 2014: an important dropout after project shutdown}

A high rate of abandonment of CA techniques (39\%) was observed in the first sample (including $75 \%$ of the farmers considered as "core adopters" with 5-8 years of CA practice and $25 \%$ of recent CA adopters: see Tab. 1). The hypothesis is that a minimum of 5 to 7 years of both practice and technical support is needed to definitively adopt $\mathrm{CA}$. The dropout rate is much higher in the North (58\%) than in the South (21\%). The difference is due to the difficulty of implementing correctly CA on tanety in rainfed conditions ( $80 \%$ of plots in the North are rainfed).

CA systems on baiboho, (colluvial soils) more present in the southern zone, seem to be more stable as definitely reducing crop failure risks. Among early adopters, the main constraints for long run CA adoption are economic (60\%) and social (57\%) (among them the factor "credit" being both economic and social). The climatic and environmental reasons for drop out occur for $47 \%$, which means that the climate-smart expected advantage of mulching is not so evident for local farmers. However and puzzlingly, a successful mulching is highly recognized as the main factor to overcome climatic erratic rainfall at early stage. Reasons put forward are in order of priority:

- increase of expenses (cited by 33\%);

- end of the extension services and discouragement $(23 \%)$;

- zebu free grazing (23\%; due to less social control, although the project did contribute significantly through "social pressure" to reinforce customary laws);

- increase of pests $(23 \%$; due to mulching and the difficulty to control them chemically);

- lack of credit facilities $(23 \%)$;

- drought (20\%).

Farmers' perceptions are derived from verbatim transcripts of focus groups compiled after meetings. CA, as a whole, is not perceived as specifically "adapted" to climatic hazards, because of:

- a risk of crop failure if the mulch is not sufficient to conserve moisture;

- strong soil compaction after 5 years. 
Table 1. Main reasons for abandoning conservation agriculture (farmers' perceptions with possibility of multiple answers).

Tableau 1. Principales raisons de l'abandon de l'agriculture de conservation (perceptions paysannes avec possibilité de réponses multiples).

\begin{tabular}{|c|c|c|c|c|c|c|c|c|c|}
\hline \multicolumn{2}{|l|}{ Social reasons } & \multicolumn{2}{|l|}{ Economic reasons } & \multicolumn{2}{|l|}{ Technical reasons } & \multicolumn{2}{|c|}{ Environmental reasons } & \multicolumn{2}{|l|}{ Other reasons } \\
\hline No extension support & $23 \%$ & $\begin{array}{l}\text { Excessive labor } \\
\text { requirements }\end{array}$ & $10 \%$ & $\begin{array}{l}\text { Increase of required } \\
\text { labor }\end{array}$ & $17 \%$ & Drought & $20 \%$ & & \\
\hline $\begin{array}{l}\text { Bushfire (linked also } \\
\text { with drought) }\end{array}$ & $3 \%$ & $\begin{array}{l}\text { Crops incompatible } \\
\text { with CA }\end{array}$ & $3 \%$ & $\begin{array}{l}\text { Difficulties to get seeds } \\
\text { for associated plants }\end{array}$ & $10 \%$ & $\begin{array}{l}\text { Soil } \\
\text { compaction }\end{array}$ & $3 \%$ & $\begin{array}{l}\text { Health problems } \\
\text { linked to } \\
\text { agrochemicals }\end{array}$ & $3 \%$ \\
\hline $\begin{array}{l}\text { Difficulties to find } \\
\text { labor force }\end{array}$ & $10 \%$ & $\begin{array}{l}\text { Disappointing } \\
\text { economic } \\
\text { performances }\end{array}$ & $3 \%$ & $\begin{array}{l}\text { Difficulties to control } \\
\text { the cover crop }\end{array}$ & $7 \%$ & & & & \\
\hline
\end{tabular}

However, with sufficient development of the cover crop (and/or sufficient crop residues) leading to good quality mulch, CA farmers could save their crops in years with low or erratic rainfall at early stage. If one of the farmers' first objective is maintaining crop production level, or even increasing it during the crop rotation, mulching appear as an opportunity to better manage rainfall patterns and not only weeds and erosion. Farmers therefore often revert to conventional techniques after a severe disappointment if the investments made do not provide significant results in the short term. Risk of crop failure at early stage appears as a key point for rainfed agriculture on tanety. If the mulch is successful, then risk is effectively reduced (crop failure by lack of water) as well as weed pressure (crop failure by competition which is linked as well with water availability). A social control of land-use including traditional grazing areas is as well highly necessary for the sustainable spreading out of CA in order to avoid biomass destruction during dry season. Many communities are not able to fully implement customary laws and regulate fines in the long run (Fevre et al., 2014).

The most important factors perceived are in priority:

- the possibility to maintain production level over the years and counterbalance the traditional decreasing yields after 2 or 3 cropping years through maintaining the original fertility;

- the possibility to crop over years without any fallow;

- the decrease of weed pressure and necessary labor to control weeds.

The other factors are:

- the decrease of the risk of crop failure with a good mulch in case of erratic rainfall;

- the possibility for a better use of water and organic or chemical manure with a good mulch as protection against erosion.
The comparison with traditional cropping systems shows clearly the potential of CA for increasing the number of cropping years per rotation: CA yields are not significantly improved but global production is doubled with the suppression of fallow over a 10 years period. A second advantage perceived by local farmers is the possibility to continuously crop cereals (rice/maize) and legumes (peanut/cowpea/rice beans/...) in association with better economic output than the usual sweet potatoes and cassava at the end of the crop cycle. When CA maintains soil fertility with good quality mulching and appropriate manure (to compensate nutrients exports), then continuous and regular production is highly appreciated by local farmers.

\subsection{Evolution of CA cropping systems on 10 year time}

Figure 2 shows the evolution of the major CA cropping systems adopted by local farmers between 2003 and 2013 on the oldest monitored plots on tanety (upland) and baiboho (colluvial soils) (77 plots). The major CA systems are those originally based on one associated plant, i.e. Brachiaria spp, Stylosanthes guianensis, Vicia villosa (vetch), Dolichos lablab (dolic) and dead mulch. Various modifications of these systems have been observed: introduction of peanut in the crop rotation (observed as well in the 3000 plots database of the BV-lac project), shift from recommended cover crops to other associated crops (dolic replaced by cowpeas for instance), re-introduction of ploughing regularly, replacement of mulch from cover crops by straw mulch (from rice from instance). The question is whether farmers tend to innovate and to install different CA patterns on more recent plots than those recommended.

Finally, we distinguish two major systems on tanety in 2013 (Fig. 2):

- the system based on the use of crop residues for mulch (rice straw or the previous year's associated plant such as $S$. guianensis or vetch) (20\%); 


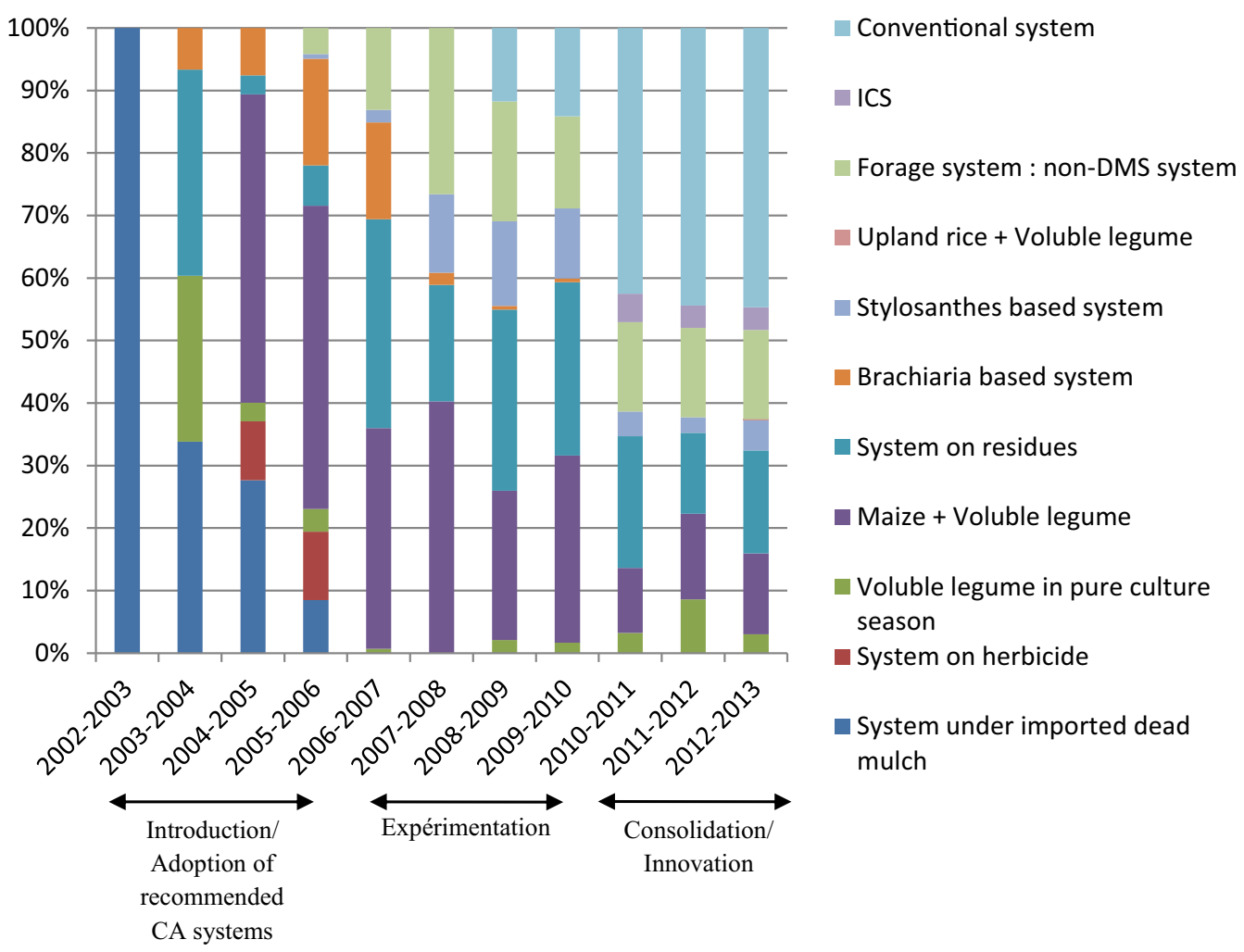

Fig. 2. Evolution and adoption of major conservation agriculture cropping systems on the oldest plots on tanety. The "Introduction phase" concerns CA systems proposed by the project and initially adopted by farmers. The "Experimentation phase" shows the different variations introduced by farmers. The last phase, "Consolidation/innovation", includes CA systems that remain (mainly rice//maize-dolic) and ICS. See Table 2 for nomenclature of cropping systems.

Fig. 2. Évolution et adoption des principaux systèmes en agriculture de conservation sur les plus vieilles parcelles en tanety. La phase «introduction » concerne les systèmes de culture proposés par le projet et initialement adoptés par les paysans. La phase « expérimentation » montre les différentes variations introduites par les paysans. La dernière phase, "consolidation/innovation 》, inclut les systèmes de cultures qui perdurent (principalement riz//mais-dolique) et les Systèmes de culture innovants (SCI). Voir le tableau 2 pour la nomenclature des systèmes de culture.

- the system "maize / twining legumes, mainly dolic" with a cover crop which normally allows the renewal of sufficient biomass $(13 \%$ to $16 \%)$, represented as the 3 last systems 2010-2013 in Figure 2 (mainly the rotation rice/maize/dolic).

Different types of legumes can be intercropped with maize: cowpea came first during 2004-2013 because it offers additional production during the main crop cycle although it does not provide significant mulch. Dolic associated with maize has largely declined since 2007 . However, dolic mulch is generally correct (in terms of biomass) but does not provide any economic return (seeds can only be used to feed porks). By comparison, the traditional crop rotation is based on rice, maize, legumes, cassava, sweet potatoes 2 to 5 years fallow (McDowall et al., 2011).

On baiboho, the main "rice / bean vetch" system stands out clearly $(20 \%)$, but we also note many other systems in smaller proportions.

In all cases, diversification of CA systems is remarkable on both topo-sequences (tanety and baiboho) with early adopters. The BV-lac project has a relative long history from 2003-2013 and has developed several approaches from a relative topdown approach at initial stage to farming system counselling and a large integrated approach including farmers' perceptions and systems evolution (Penot et al., 2014, 2015). It should however be noted that since 2010, despite a strong observed global dropout, present systems are relatively stable. Until 2010, farmers were testing the recommended CA systems by themselves. Innovative farmers have further developed this "experimental" phase after 2010 and have tailored major systems to their needs (phase of "appropriation"). Instead, the "recent CA" farmers (surveyed in Ambandrika, North area) are still in a phase of adoption as techniques have hardly changed over baiboho recommended systems.

Since 2010, we did observe a strong endogenous development of ICS (Innovative Cropping Systems) demonstrating both willingness from farmers to adapt cropping systems and maintain some CA functions considered as crucial. In 2013, ICS represent 4\% of "oldest" tanety plots (10 years), $15 \%$ of "new" tanety plots (less than 5 years) and $12 \%$ of baiboho plots. ICS large diffusion inside and outside project area shows an indirect successful impact of the project (authors assessment). ICS are farmer' innovations, through technical changes to simplify the original CA systems, and prove to be very effective at least for local farmers. A complementary survey implemented in 2013-2014 (not presented in this paper: Fevre et al., 2014) shows that most project's former farmers do now implement ICS. The absence 
Table 2. Nomenclature of cropping systems implemented on tanety in 2013 as used in Figures 3 and 4.

Tableau 2. Nomenclature des systèmes de culture développés sur tanety en 2013, comme indiqué dans les figures 3 and 4.

\begin{tabular}{|c|c|}
\hline $\begin{array}{l}\text { Cropping } \\
\text { systems }\end{array}$ & Definition \\
\hline $\mathrm{T} 1$ & Maize + Voluble legume//Upland rice \\
\hline $\mathrm{T} 3$ & Introduction of groundnut in the basic rotation of $\mathrm{T} 1$ \\
\hline $\mathrm{T} 4$ & $\begin{array}{l}\text { Introduction of upland rice in the continuous system } \\
\text { "Maize + Voluble legume" }\end{array}$ \\
\hline T5 & Maize based continuous system \\
\hline T6 & $\begin{array}{l}\text { Introduction of "cassava }+ \text { stylosanthes" in the basic } \\
\text { rotation of } \mathrm{T} 1\end{array}$ \\
\hline $\mathrm{T} 7$ & $\begin{array}{l}\text { Crop rotation not stabilized (according to local annual } \\
\text { opportunities including groundnut) }\end{array}$ \\
\hline T8 & $\begin{array}{l}\text { Maize + Voluble legume//Maize + Voluble legume// } \\
\text { Upland rice }\end{array}$ \\
\hline T9 & Cassava based continuous system \\
\hline T9-b & Vetch based continuous system \\
\hline $\mathrm{T} 10$ & Rice + stylosanthes $/ /$ maize + stylosanthes \\
\hline $\mathrm{T} 11$ & Bean + stylosanthes //Cassava + stylosanthes \\
\hline
\end{tabular}

NB: All crops on tanety are rainfed with associated crops that remain during part of the dry season, leading to a mulch.

of extension services probably explains the emergence of ICS. Mulching is probably the most interesting component. However, the necessity to grow an additional cover crop with no immediate economic returns does prevent some farmers to benefit from this advantage.

\subsection{Crop rotations implemented by the "oldest adopters"}

Table 2 and Figures 3 and 4 show the current cropping systems effectively adopted by farmers in 2013 on tanety. The original system nomenclature from Raharisoa et al. (2012) has been adapted with 4 new innovative systems (T8 to T11). On tanety, the main systems are the rotation maize + legume / rainfed rice / peanut ( $43 \%$ of the sample) in the North and the continuous maize/dolic system in the South (46\%). On baiboho, $70 \%$ of the areas are under the continuous system rice / bean or pea / vetch. Whether on tanety or baiboho, there is a wide diversity of technical pathways. Cereal/legumes crop rotation without fallow, no tillage (at least most of time) and integration of a "service" plant (generally a leguminous) are definitely new compared to conventional systems. One main trend of farmers' change is the replacement of not economically productive recommended associated "service" plants by more productive ones (such as peanut) but producing far less biomass for mulch.

As usual in term of risk management, immediate economic output is preferred by most farmers to mid-term fertility improvement or even immediate climatic advantage in case of erratic rainfall. This leads to an increase of what we called "opportunistic till" when tillage remains the only option to control weeds. There is then a shift from CA to ICS. Weed control, tillage and no-tillage, quality of the mulch and rainfall

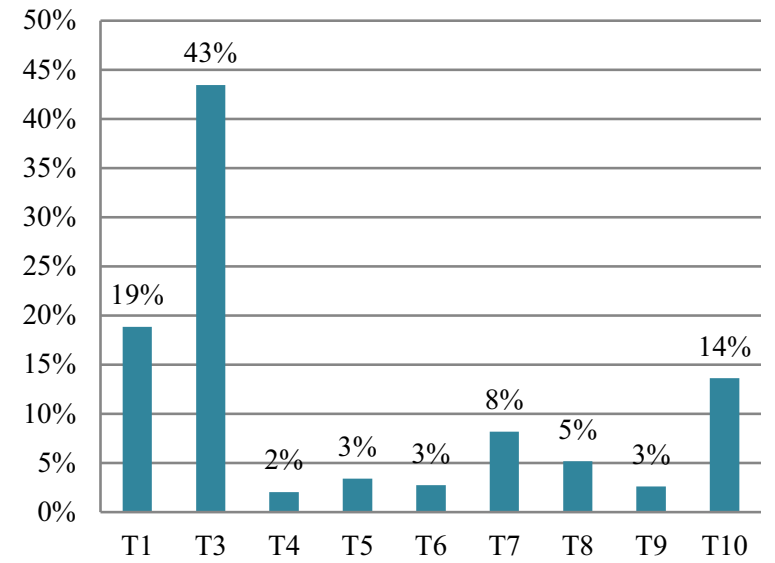

Fig. 3. Cropping systems in percentage of surface on tanety in the Northern zone. See Table 2 for nomenclature of cropping systems. Fig. 3. Systèmes de culture en pourcentage des surfaces en tanety dans la zone Nord. Voir le tableau 2 pour la nomenclature des systèmes de culture.

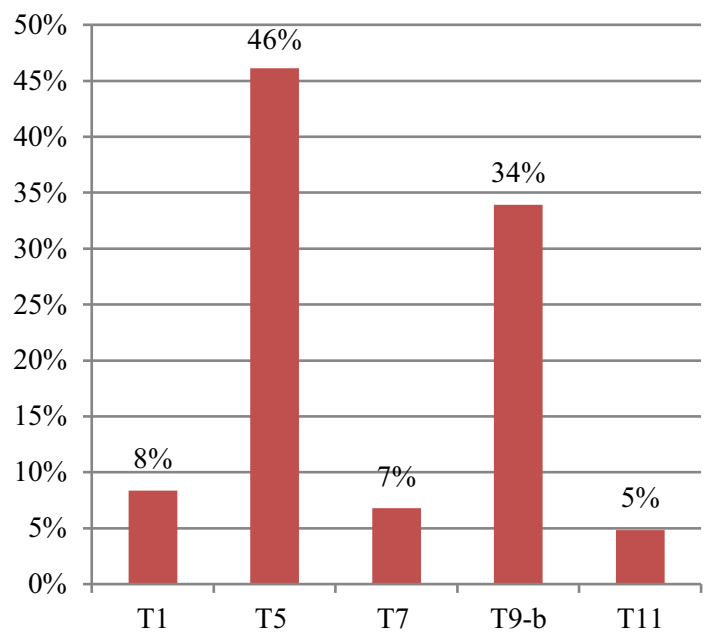

Fig. 4. Cropping systems in percentage of surface on tanety in the Southern zone. See Table 2 for nomenclature of cropping systems.

Fig. 4. Systèmes de culture en pourcentage des surfaces en tanety dans la zone Sud. Voir le tableau 2 pour la nomenclature des systèmes de culture.

pattern are jointly taken into account in farmers' decision when choosing a CA/ICS system and its related practices. Risk assessment is behind every farmers' choice according to his or her own situation (Penot et al., 2014). One important feature is that we cannot talk about any comparison between "traditional" (called here "conventional") and CA systems since many farmers transform continuously their cropping systems, which hence are not any more "traditional". If Teissonier and Penot (2013) show that CA "stricto sensu" as a whole was not adopted outside the project, McDowall et al. (2011) and Poletti et al. (2011), and project plots monitoring (on 3000 plots) over the years show that ICS were widely adopted by project and even non-project farmers although it has never been formally measured. It would be very interesting to measure such impact. Local farming systems surveys (Durand et al., 2011) show that 


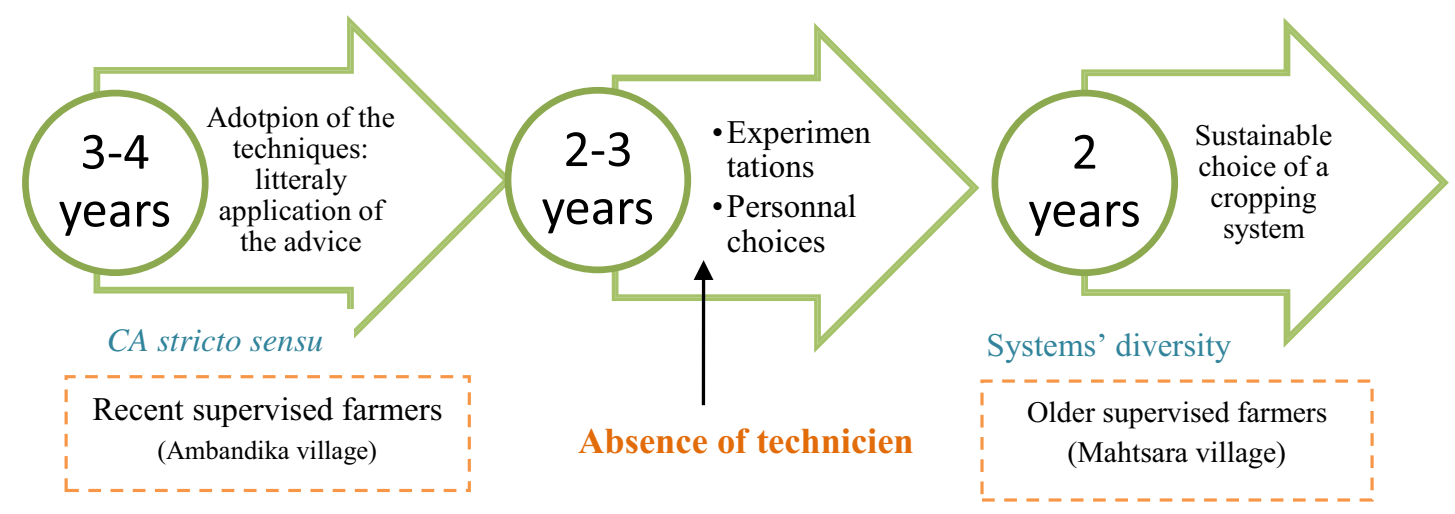

Fig. 5. Innovation adoption scheme for conservation agriculture.

Fig. 5. Schéma d'adoption et d'innovation pour l'agriculture de conservation.

all technical components of 1980's research development projects, carried out by CIRAD (French Agricultural Research Centre for International Development) and FOFIFA (Malagasy National Centre for Research Applied to Rural Development) have been integrated into current cropping systems at various degrees 30 years after introduction.

On tanety, cropping systems require a proper management of associated cover crop and rotation as they are more complex to master compared to those on baiboho where the main system "upland rice / bean vetch" is easy to implement due to water access in the dry season and allows a good economic return. In other words, the "cost" of associated plant (vetch) is offset by the increased production of the main crop (rice). Tillage remains necessary at regular intervals (every 3 to 5 years) for soil de-compaction, showing that associated plants are not effective enough to replace tillage.

Most farmers aim to increase overall production per hectare to improve their income during the counter-season and favor more productive associated crops (beans, cowpeas, rice beans). On tanety, the goal is often to increase rapidly farmers' income with the introduction of peanuts in a triennial rotation with maize and rice. One main advantage of CA is the suppression of the fallow period. Stable production levels and continuous cropping with CA lead rapidly to the necessity to manage soil fertility. Crop diversification is a way to benefit from the economic crop opportunities (good market prices) and to minimize crop failure risk. However, production intensification is often done at the expense of the cover plant used for mulching, requiring more frequent "opportunistic" tillage in the rotation. Thus, $50 \%$ of the cropping systems on baiboho and $70 \%$ on tanety are no longer CA systems, stricto sensu, but tend to be ICS. Figure 5 presents a synthesis of the temporal process of adoption and innovation by farmers (2003-2013). The trend of going back to a triennial rotation with rice/maize/peanut is a legacy of CIRAD-FOFIFA's research development projects in the same area in the 1980's (Ogier, 1989). At that time, long before CA existed, new inputs were recommended. It seems quite necessary therefore to implement in the next future a large cropping systems survey that could measure ICS impact and long term innovation process since the 1980's, including use of various types of inputs (from herbicides to chemical manure), CA techniques, use of manure on tanety, etc.

Either 30 years ago with research development projects or during the BV-lac project in 2003-2013, cropping system adaptation and recombination of knowledge and know-how are linked. They are influenced by the social context (not very favorable for farmers' structuration), by the economic expectations and by farmers' ability to seize opportunities (Beguin and Cerf, 2009). Innovation processes that result from various projects in the last 40 years are still present in this area. A large survey and impact assessment of these changes would yield very interesting data, since no big development project is present in the area any more.

\subsection{SWOT analysis on CA sustainability}

The SWOT analysis results display pros and cons of CA and key answers to the main constraints (Tab. 3 ) as perceived by farmers. Although 55\% of the producers have confirmed that they do perceive a yield increase (under strong impact of the presence of BV-lac project extensionists since many years), this is difficult to confirm with regard to existing project databases and surveys. McDowall et al. (2011) showed in this same area that the CA yield increase over 5 years was limited to 10 to $15 \%$ when Bruelle (2014) observed a $20 \%$ increase (low input systems with no chemical fertilization). The most commonly shared feeling by farmers is that yields in CA are maintained over the years compared to declining yields in traditional systems. The most significant result for farmers is the doubling of global production over 10 years with the disappearance of the fallow period. This yield increase, combined with the protecting effect of mulching in case of erratic rainfall at planting, give CA some climate-smart attributes. A visual assessment confirmed that about $50 \%$ of the plots had sufficient mulch. Table 4 summarizes the characteristics that can influence the adoption of CA techniques.

\subsection{Contrasted farmers' behavior between early and late CA adopters}

A typology of farmers' behavior was performed in 2013 in order to characterize farmers' attitudes after project completion, according to two criteria:

- the level of autonomy in CA adoption;

- the importance of project linkage through the presence of technicians.

Table 5 summarizes the different types of behaviors. "Autonomous" farmers $(40 \%$ of the remaining CA farmers 
Table 3. SWOT Analysis (strengths, weaknesses, opportunities, threats).

Tableau 3. Analyse SWOT (forces, faiblesses, contraintes et opportunités).

\begin{tabular}{|c|c|c|c|}
\hline Strengths & Weaknesses & Opportunities & Threats \\
\hline $\begin{array}{l}\text { Improvement of soil structure, } \\
\text { fertility and moisture }\end{array}$ & Pests increase & $\begin{array}{l}\text { Spontaneous spread between CA } \\
\text { and non CA farmers }\end{array}$ & $\begin{array}{l}\text { Lack of organisation between } \\
\text { producers and supply problems } \\
\text { for seeds, and inputs }\end{array}$ \\
\hline
\end{tabular}

Table 4. Main features on tanety and baiboho for adoption of conservation agriculture (farmers' perceptions).

Tableau 4. Principales caractéristiques sur Tanety et Baiboho pour l'adoption des systèmes en agriculture de conservation (perceptions paysannes).

\begin{tabular}{lll}
\hline & Baiboho & Tanety \\
\hline Access to water in dry season & Good & No \\
Fertility & Colluvial soils with good fertility & Rather poor \\
Potential associated cover crops & Almost all of them & Restricted choice: $S$ guianensis, D. lablab, Mucuna spp \\
CA adoption & Relatively easy and less risky & Relatively difficult and more crop failure risk \\
Other constraints & Weed management & Risk of associated crop failure with no mulch eventually \\
\hline
\end{tabular}

Table 5. Types of behavior of farmers.

Tableau 5. Types de comportement des paysans.

\begin{tabular}{|c|c|c|c|}
\hline 1st criteria & 2nd criteria & Type of behaviour & Number of farmers \\
\hline & Lack of supervision with direct impact on CA surfaces & Not autonomous & $16(22 \%)$ \\
\hline CA Non-command / know-how & Need for permanent assistance & Never autonomous & $6(8 \%)$ \\
\hline
\end{tabular}

after dropout) clearly stated that they do not perceive any change of CA practices following project shutdown and have generally increased their CA cropped area since 2009. The "enquirer" farmers $(30 \%)$ feel autonomous but expressed a preference for a continuous technical assistance. On the contrary, the "non-autonomous" farmers (22\%) might master CA but also feel the need for a permanent technical assistance, and do not maintain CA in the long run. These producers decreased their CA cropped areas and even lately abandoned CA, for most of them $(81 \%)$. The latest group $(8 \%)$ never mastered CA and will never be autonomous. Such situation suggests that most farmers do master CA (92\%) and do not consider CA as too "sophisticated". But mastering CA, after 5 or 7 years of practice, does not lead to an automatic long run adoption. Among economic expected benefits, better yields $(55 \%)$, reduced labor requirement $(30 \%)$ and moisture maintenance with mulch to secure sowing (28\%), appear first in the focus group discussions as well as during discussion with survey \# 1 farmers. Other benefits mentioned are soil fertility, soil erosion and risk management against drought $(8 \%)$. Farmers' decision about CA adoption is a mix between economic expectations (more important in the long run), risk avoidance (both climatic and price volatility) and maintenance or improvement of soil fertility to secure production, as well as more flexibility in general crop management. We did not find specific differences between farmers types. Table 6 displays the balance between positive and negative perception on CA adoption as a synthesis of focus group analysis and authors' perception and illustrate that economic and social factor are key component for CA adoption.

\section{Conclusion}

In a 10-year time, CA cropping systems are extremely diverse, showing that producers do innovate in particular when they move partly to ICS. The high dropout rate since the completion of the project shows that a minimum of 5-7 years 
Table 6. Balance between positive and negative perceptions on adoption of conservation agriculture (synthesis between focus group analysis and authors).

Tableau 6. Perceptions paysannes positives ou négatives concernant l'adoption des systèmes en agriculture de conservation (synthèse entre l'analyse des focus groupes et les auteurs).

\begin{tabular}{|c|c|c|}
\hline & Positive perception & $\begin{array}{l}\text { Negative perception and constraints to sustainable CA } \\
\text { adoption }\end{array}$ \\
\hline $\begin{array}{l}\text { Cropping } \\
\text { system level }\end{array}$ & $\begin{array}{l}\text { Less tillage, Crop rotation } \\
\text { Suppression of fallow, Line planting } \\
\text { Potential crop yield increase over the years } \\
\text { Intensification in number of crops per cycle (plant } \\
\text { association) } \\
\text { Large diffusion of ICS }\end{array}$ & $\begin{array}{l}\text { The } 3 \text { principles of CA are rarely all adopted } \\
\text { Covercrop / associated crop / mulch management } \\
\text { Associated plant seed management } \\
\text { Understanding of role and impact of associated plants in } \\
\text { CA systems }\end{array}$ \\
\hline $\begin{array}{l}\text { Farming system } \\
\text { level }\end{array}$ & $\begin{array}{l}\text { Less manure on CA plots }=\text { more manure on other plots } \\
\text { Better farming management linked with the use of } \\
\text { notebook and income calculation }\end{array}$ & $\begin{array}{l}\text { No real improvement in terms of agriculture / livestock } \\
\text { integration } \\
\text { No diffusion of CA on the total farm upland area } \\
\text { Strategy of crop risk minimization poorly compatible with } \\
\text { CA adoption during the first years on tanety }\end{array}$ \\
\hline
\end{tabular}

of practice is needed to secure CA adoption. Farmers' strategy focuses on risks minimization. Nevertheless, a major technical difficulty appears in the management of mulch, a key factor to secure crops if erratic rainfall occurs. A "core of CA adopters" still does exist but is much smaller than originally expected. For $25 \%$, it seems that a change of "paradigm" has actually fully occurred with a clear desire to better manage fertility, risks and sustainability. These farmers are fully convinced of the effectiveness and benefits of CA (Penot et al., 2015).

There is a continuum of technical pathways between CA, ICS and conventional systems, showing a high diversity of systems and a strong innovation capability. On the other hand, ICS, arising from diffusion of CA extension on large scale, seem now much more present across the lake (although no census has been done yet). Increasing the number of profitable crops in rotation, and using less fertilizer through the use of leguminous cover crops (green manure) may increase economic returns. However, ICS, although more easily adoptable, may not have the same environmental benefits than CA and do not lead to significant increase in economic performance. In summary, the real adoption of CA stricto sensu in the long run is very low.

Although the BV-Lac project has created favorable conditions for the emergence and dissemination of $\mathrm{CA}$, it seems that this may not work if there is no long-term active participatory approach or partnership with farmers in the context of sustainable farm groups or associations. The CA paradigm shift calls for a rethinking of extension methods. CA adoption requires the integration of mid or long-term strategies in farmers' perspective. CA requires technical innovation, always linked with economic and sociological aspects. It also requires a specific policy environment based on farmers' real constraints and strategy, coupled with a learning process. As CA techniques are relatively known by former projects' farmers, further emphasis should be put on how to improve extension for ICS to benefit from the large array of systems' diversity that emerges from CA extension.

Although CA and its modified versions (ICS) have the capacity to buffer climatic variations at planting, it is not clear whether these practices can significantly contribute to climate change mitigation. Further studies are necessary to assess impact of CA and ICS from a large sample of the original 3000 farmers involved during the 10 years BV-Lac project duration.

Acknowledgements. The authors thank Daphne Goodfellow, Guy Trébuil and Emmanuel Torquebiau for their contributions to the final version of this paper.

\section{References}

Andersson JA, D'Souza S. 2014. From adoption claims to understanding farmers and contexts: a literature review of Conservation Agriculture (CA) adoption among smallholder farmers in southern Africa. Agric Ecosyst Environ 187: 116132. DOI: $10.1016 /$ j.agee.2013.08.008.

Arslan A, McCarthy N, Lipper L, Asfaw S, Cattaneo A. 2014. Adoption and intensity of adoption of conservation farming practices in Zambia. Agric Ecosyst Environ 187: 72-86. DOI: 10.1016/j.agee.2013.08.017.

Beguin P, Cerf M. 2009. Dynamique des savoirs, dynamiques des changements. Toulouse: Octarès Editions, collection Travail et activité humaine, ISBN 978-2-915346-72-5, 308 p. 
Brevault T, Bikay S, Maldes JM, Naudin K. 2007. Impact of a no-till with mulch soil management strategy on soil macrofauna communities in a cotton cropping system. Soil and Tillage Research 97(2): 140-149. DOI: 10.1016/j.still.2007.09.006.

Bruelle G. 2014. Pertinence de l'agriculture de conservation pour tamponner les aléas climatiques : cas des systèmes de culture en riz pluvial au lac Alaotra, Madagascar. Thèse de doctorat. Antananarivo: Université d'Antananarivo, $110 \mathrm{p}$. https://agritrop.cirad.fr/ 575511/1/document 575511.pdf.

Bruelle G, Naudin K, Scopel E, Corbeels M, Torquebiau E, Penot E et al. 2015. Is conservation agriculture a climate-smart option for smallholders in sub-Saharan Africa? An overview. Climate-Smart Agriculture 2015. Montpellier(France): Global Science Conference, 16 p. http://agritrop.cirad.fr/576396/.

Corbeels M, Scopel E, Cardoso A, Bernoux M, Douzet JM, Siqueira Neto M. 2006. Soil carbon storage potential of direct seeding mulch-based cropping systems in the Cerrados of Brazil. Global Change Biology 12: 1773-1787.

Corbeels M, de Graaff J, Ndah TH, Penot E, Baudron F, Naudin K et al. 2014. Understanding the impact and adoption of conservation agriculture in Africa: a multi-scale analysis. Agric Ecosyst Environ 187: $155-170$.

Derpsch R. 2005. The extent of CA adoption worldwide: implications and impact. Keynote paper presented at the III World Congress on Conservation Agriculture, Nairobi, Kenya, October 3-7, 2005.

Durand C, Nave S, Penot E. 2011. Les paysans de l'Alaotra, entre rizières et tanety Madagascar. Dynamiques agraires, stratégies paysannes et mise en place d'un réseau de fermes de référence. In : Penot E, ed. Exploitations agricoles, stratégies paysannes et politiques publiques: les apports du modèle Olympe. Versailles: Quae, pp. 117-129.

FAO. 2008.Investing in sustainable agricultural intensification. The role of conservation agriculture. A framework for action. Rome: Food and Agriculture Organization of the United Nations.

Fevre V, Flodrops P, Penot E. 2014. Étude des trajectoires d'innovations et modes d'adoption sur l'agriculture de conservation dans la région du lac Alaotra: résultats des enquêtes 2 et 3. Document de travail UMR Innovation. Montpellier: Cirad, $39 \mathrm{p}$. DOI: $10.13140 /$ RG.2.1.1415.4408.

Findeling A, Ruy S, Scopel E. 2003. Modeling the effects of a partial residue mulch on runoff using a physically based approach. Journal of Hydrology 275(1-2): 49-66.

Giller K, Witter E, Corbeels M, Tittonell P. 2009. Conservation agriculture and smallholder farming in Africa: the heretics' view. Field Crop Research 114(1): 23-34.

McDowall C, Poletti S, Penot E, Domas R. 2011. Synthèse sur les systèmes de cultures conventionnelles (non SCV) au lac Alaotra. Document de travail BV lac $\mathrm{n}^{\circ}$ 83. Paris: AFD, 16 p. https:// agritrop.cirad.fr/564307/1/document_564307.pdf.

Naudin K, Scopel E, Andriamandroso ALH, Rakotosolofo M, Andriamarosoa Ratsimbazafy NRS, Rakotozandriny J de $\mathrm{N}$ et al. 2012. Trade-offs between biomass use and soil cover. The case of rice-based cropping systems in the Lake Alaotra region of Madagascar. Experimental Agriculture 48: 194-209. DOI: 10.1017/S001447971100113X.

Ogier J, 1989. Zonage du lac AIaotra. Projet recherche-développement, Mmagri/SOMALAC, FOFIFA-DRD, CIRAD-SAR. Montpellier (France) : Cirad, $137 \mathrm{p}$.
Penot E, Macdowall C, Domas R. 2012. Modeling impact of Conservation Agriculture adoption on farming systems agricultural incomes. The case of lake Alaotra Region, Madagascar. CA2AFRICA project. Seminar IFSA, Denmark, July 2012.

Penot E, Dabat MH, Andriatsitohaina T, Grandjean P. 2014. L'évolution des pratiques agricoles au lac Alaotra à Madagascar. Une approche par les temporalités. Biotechnologie, Agronomie, Société et Environnement 18: 329-338. http://www.pressesagro.be/base/ index.php/base/article/view/756.

Penot E, Domas R, Fabre J, Poletti S, Macdowall C, Dugué P, et al. 2015. Le technicien propose, le paysan dispose. Le cas de l'adoption des systèmes de culture sous couverture végétale au lac Alaotra, Madagascar. Cahiers Agricultures 24: 84-92. DOI: 10.1684/agr.2015.0745.

Poletti S, Penot E, Domas R. 2011. Évaluation technico-économique de l'impact de l'adoption des SCV sur les exploitations agricoles de la région du lac Alaotra, Madagascar. Partie 3 : résultats sur la modélisation des exploitations agricoles et des principaux systèmes de culture SCV (évolution sur 10 ans). Document de travail BV-lac $\mathrm{n}^{\circ}$ 73. Paris: AFD, 26 p. https://agritrop.cirad.fr/562866/1/docu ment_562866.pdf.

Raharisoa B, Penot E, Domas R, Rakotondravelo JC. 2012. Évolution des processus d'innovation des SCV pour la rive Est du Lac Alaotra. Partie 3. Principaux résultats des systèmes de culture. Document de travail BV lac $\mathrm{n}^{\circ}$ 86. Paris: AFD, $27 \mathrm{p}$. https:// agritrop.cirad.fr/565850/1/document_565850.pdf.

Scopel E, Da Silva FAMM, Corbeels M, Affholder F, Maraux F. 2004. Modelling crop residue mulching effects on water use and production of maize under semi-arid and humid tropical conditions. Agronomie 24: 383-395. DOI: 10.1051/agro:2004029.

Scopel E, Findeling A, Guerra EC, Corbeels M, Copel ES, Indeling AF et al. 2005. Impact of direct sowing mulch-based cropping systems on soil carbon, soil erosion and maize yield. Agronomy for Sustainable Development 25: 425-432. DOI: 10.1051/ agro:2005041.

Scopel E, Triomphe B, Affholder F, Da Silva FA, Corbeels M, Valadares Xavier JH et al. 2012. Conservation agriculture cropping systems in temperate and tropical conditions, performances and impacts. A review. Agronomy for Sustainable Development 33: 113-30.

Serpantié G. 2009. L'agriculture de conservation à la croisée des chemins. Vertigo 9(3). http://journals.openedition.org/vertigo/ 9290 .

Teissonier A, Penot A. 2013. Analyse des modes d'appropriation et d'adoption des techniques de l'agriculture de conservation hors projet dans la zone du lac Alaotra, Madagascar. Document de travail UMR innovation/DP SPAD. Montpellier: Cirad, $36 \mathrm{p}$. https://agritrop.cirad.fr/587025/1/ID587025.pdf.

Vanlauwe B, Wendt J, Giller KE, Corbeels M, Gerard B, Nolte C. 2014. A fourth principle is required to define conservation agriculture in sub-Saharan Africa: the appropriate use of fertilizer to enhance crop productivity. Field Crop Res 155: 10-13. DOI: 10.1016/j.fcr.2013.10.002.

Wezel A, Casagrande M, Celette M, Vian J-F, Ferrer A, Peigné J. 2014. Agroecological practices for sustainable agriculture. A review. Agronomy for Sustainable Development 34: 1-20. DOI: 10.1007/s13593-013-0180-7. 